when the vapor pressure of monomer was high. The grafted fibers contained the large amount of the occluded homopolymer. The grafting reaction process, and the dependency of the rate of grafting on the temperature, vapor pressure, and dose-rate were well explained by taking into account of the increase in sorption caused with the increase in the extent of grafting.

（日本化学会誌，1972，p. 1943～1948）

\title{
トリブチルボランによるメタクリル酸メチルの 絹へのグラフト共重合
}

(1972 年 3 月 15 日受理)

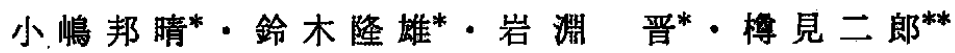

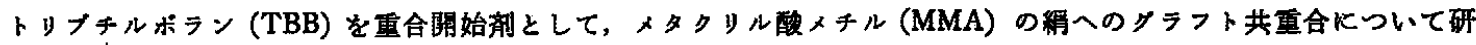
究した。

絹が存在する场合は，綃のない場合にくらベて重合が促進され，絙のグラフト共重合体が生成する。この反応恃温

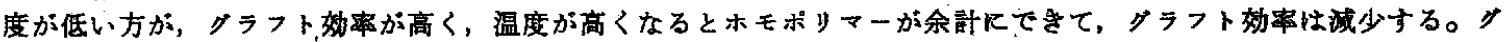

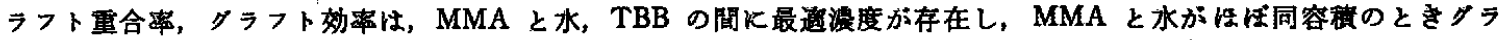
フト重合率は最大となる。水が存在しないときにはダラフト重合体ははとんど得られない。䊘の量を增した场合は全

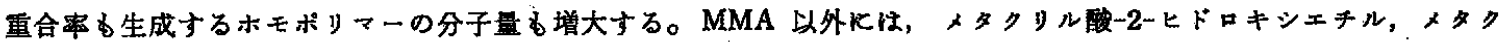

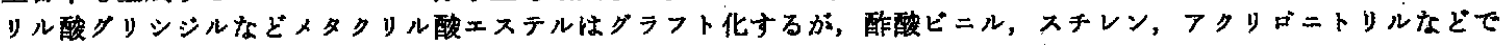
はグラフト化は起こらなかった。

またグラフトポリマーの加水分解生成物のフミノ酸分析を行ない,一部のアミノ酸残基がクラフト化に関与してい ることを推定した。以上の事実から TBB と編と MMA の間で活性コンブレックスを生成し，グラフト共面倉が起 こると考えられる。
\end{abstract}

\section{1 楮专}

天然高分子や合成高分子へのビニル化合物のグラフト共重合は 放射線, 過硫酸塩, セリウム塩などを用いて行なわれすでに多 くの研究が報告されているり。著者らはすでにアルキルボランを 重合開始剤とする新しいグラフト共重合の方法を見いだし，これ について報告した ${ }^{2) 9}$ アルルルボランを使用すると常温でとく Kタンパク質にグラフト化しやすく、コラーゲンタ)，編，羊毛， アルブミン4)などとグラフト重合する。また血液中でメタクリル 酸メチル(MMA)を重合すると, 主としてへモグロビンのダラフ 卜共重合体が得られることを知った6)6)。そこでへモグロビンへ のグラフト共重合について詳細な検討を加えだ。一方，編は光

* 千葉大学工学部合成化学科, 千葉甫弥生町

**東京医科科犬学医用器材研究所, 東京都千代田区神田睃 河台

1) たとえば, H. A. J. Battaerd, G. W. Tregear, “Graft Copolymers", John Wiley.\& Sons (1967) p. 17.

2) K. Kojima, S. Iwabuchi, K. Kojima, N. Tarumi, J. Polym. Sci., B-9, 25(1971).

3）增原英一，小嶋邦晴，博㒻二郎，他，東医歯大 - 材研報， 2(9), 788(1966).

4）小鳴邦晴, 岩淵 晋, 小鳥幸一, 村上国夫, 千桨大学工学 部研究報告, 23(43)，65(1971).

5) K. Kojima, S. Iwabuchi, K. Kojima, N. Tarumi, $J$. Polym. Sci., B-9, 453(1971).

6) K. Kojima, S. Iwabuchi; K. Kojima et al., J. Polym. Sci., $A-1$, 9, 3213(1971).
沢や風合のすぐれた織維で，古くから使用されているが，酎光性 がそしく黄変しやいことや，しわになりやすい欠点があった。こ の欠点を改善するために，絹への種々のビニル化合物のグラフト 共重合が研究されている。たとえば，祖父江，昖崎ら 光性を改善するためににフクリル酸カルシウムをグラフト共重合し，

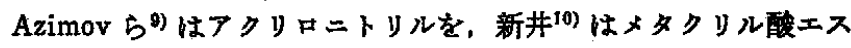
テルを, 村瀬ら ${ }^{1112)}$ はアクリルアミドならびにスチレンのグラフ 卜共重合によってその性質の改善を陚みている。これらはいずれ も放射線，過酼酸塩，セリウム塩などを重合開始郕として用いて いるが，最近井本ら ${ }^{13)}$ は無触媒でも綟存在下K MMA を加䓡す るだけで,グラフト共重合体が得られると報告している。しかし 一般的炕は高温でグラフト重合を行ならとホモポリマーが多くな ク，手ざかりや光沢が悪くなることがわかっている(1)16)。

著者らはアルキルボランを重合開始剤として，常温で絹にグラ

7) K. Kojima, S. Iwabuchi, K. Kojima, N. Tarumi, Bull. Chem. Soc. Jap., 44, 1891(1971).

8）祖父江 宽，松崎 㤵，村上健吉，維学誌，10，582(1954).

9) S. A. Azimov, Kh. U. Usmanov, N. V. Kordub, S. I. Slepakova, Chem. Abstr., 55, 19252(1961) ; 58, 4677 (1963).

10）新井幸三，根岸道治，禨学誌，23，595(1967).

11）村頪良一，杉山弘子，機工試報，70，37(1964).

12）松村圭子，村瀬良一，維工試報，82，39(1967).

13）井本 稳, 近藤 充, 竹本串一, 工化, 68, 1302(1965).

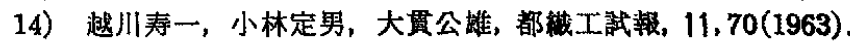

15）小林定男，大貫公婎，都機工陚報，12，66(1964). 
フト共重合することを試み，興味ある知見を得た。その結果を報 告する。

\section{2 実験}

\section{2,1 实験材料}

2.1.1 トリブチルボラン：トソブキルボラン(以下 TBB と 略記する) は市肘品 (Callery Chemical Co.) Dry Box 中窒 秦気流中で减圧弥留し, bp $90 \sim 92^{\circ} \mathrm{C} / 10 \mathrm{mmHg}$ の留分をとり， Dry Box 中で $0.5 \mathrm{~m} l$ 容量のアンブルk 0.1 0.2 ml ずつ採取, 封入し，実卧にさいしてアンプルを開封して使用した（文献值 ${ }^{16)}$ bp $108 \sim 110^{\circ} \mathrm{C} / 20 \mathrm{~mm} H g d^{26} 0.747$ )。

2.1.2 絹: 家虫の絧系を 炭酸ナトリウムホ溶液で 1 時間煮沸 し，本洗螒燥する。ついで熱つセトンで可溶珄成分を抽出したの ち、メタノールで洗淨し、メタノールを除去したのちに、はしめ はデシケーター中で，後代真空乾燥器中で佰量飞なる主で乾燥す る。このようにして精製した絧釆峐化カルシウムデシケーター 中に入れ $20^{\circ} \mathrm{C}$ の佰温室中で 2 䢙間以上放置し使用した。

2.1.3 メタクリル酸メチルならひにその誘導体の精製：市眅 メタクリル酸メチル（以下 MMA と略記する） $1 l$ を分液漏斗 Kとり， $100 \mathrm{~m} l$ の酸性正硫酸ナトリウム飽和水溶液で 3 回洗浄 し，つぎ $100 \mathrm{ml}$ の $5 \%$ 水酸化ナトリウム水溶液で 3 回洗浄 し, 最後に $100 \mathrm{ml}$ の $20 \%$ 食塩水溶液で洗浄したのちに，無水 硫酸ナトリウムを加えて一夜放置する。ついで乾燥剤を口過し， イオウ華 $1 \mathrm{~g}$ を加えて窒妻気流中で減圧蒸留し使用した。bp $52^{\circ} \mathrm{C} / 170 \mathrm{mmHg}$ (文献值 ${ }^{17)} 46^{\circ} \mathrm{C} / 100 \mathrm{mmHg}$ )。

メタクリル酸グリシジル(GMA), メタクリル酸-2-七ドロキシ エチル (HEMA), アクリル酸エチル (EA), 酢酸ピニル (VAc), アクリロニトリル（AN)，ならびにスチレン (St) 恃市眅品を窒 索気流中で減圧蒸留して精製しただちに使用した。沸点ならびに 文献値はつぎのとおりである。

GMA : bp $93 \sim 94^{\circ} \mathrm{C} / 20 \mathrm{mmHg}$ (文献值 ${ }^{18)} 57 \sim 59^{\circ} \mathrm{C} / 3 \mathrm{mmHg}$ ) HEMA : bp $84^{\circ} \mathrm{C} / 5 \mathrm{mmHg}$ (文献值 $\left.{ }^{19}\right) 85 \sim 86^{\circ} \mathrm{C} / 5 \mathrm{mmHg}$ )

VAc : bp $19 \sim 20^{\circ} \mathrm{C} / 86 \mathrm{mmHg}$ (文献値㬏 $73^{\circ} \mathrm{C}$ )

EA : bp $19.5^{\circ} \mathrm{C} / 28 \mathrm{mmHg}$ (文献値 ${ }^{21)} 99.5 \sim 100^{\circ} \mathrm{C}$ )

AN : bp $77^{\circ} \mathrm{C}$ (文献値 ${ }^{22)} 77.3^{\circ} \mathrm{C}$ )

St : bp $43^{\circ} \mathrm{C} / 18 \mathrm{mmHg}$ (文献值 ${ }^{28}$ ) $145.2^{\circ} \mathrm{C}$ )

\section{2 英験方法}

2.2.1 クラフト共重合 : 内容 $60 \mathrm{~m} l$ の硬筫ガラス製重合管に 絧（単織維）を秤量して入れ，一定量の水で 24 時間膨潤させる。 そしてこの中に央験直前とアンプルから取り出した TBBの一定 量を加えた MMA を添加し，37ㄷ調節した佰温フリマゼ器内 で一定時間重合させた。反応混合物は $10 \%$ のアンモニア水を加 えた $150 \mathrm{~m} l$ のメタノール中に注いで重合体を分離し，得られた 重合体はグラスフィルターでロ過したのち、はじめは減圧デシケ

16) Callery Chemical Co. Catalogue.

17) 神原周, 他, “単量体合成法”(高分子実験学粨座 9 ), 共 立出版 (1957) D. 140.

18) J. G. Erickson, U. S. P., 2, 567, 842 (1951).

19）文献 17) の p. 143.

20) 文献 17) 9 p. 45.

21）文献 17）の p. 134

22）文献 17）の p. 157 .

23）文献 17）の p. 78 .
ーター中で，ついで真空乾燥器中で恒量化なるまで乾燥した。

本系泩不均一系の重合反芯であるから，ふりまぜのさい性つね に一定の速度で，一定の角度で方りまぜるよらにとくに注意して 行なった。

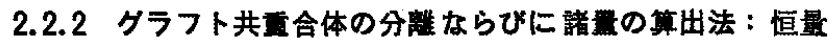
となった重合体は Soxhlet 抽出器を用い 48〜72 時間(4) 抽出を 行ない，抽出されたホモポリマーは大過翻のメタノールで沈䟝さ せ，前と同様にグラスフィルターで口過乾燥する。一方，不溶性 ポリマーす同様に競煤して秤量しグラフトポリマー量とした。つ いで式（1）（3）火よって全重合率，グラフト重合率，ならび にグラフト効率を算出した。

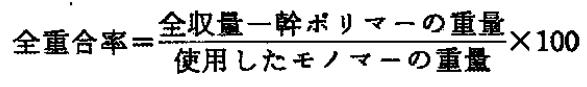

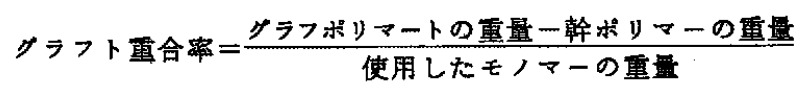

$\times 100$

$$
\text { グラフト奻率 }=\frac{\text { グラフトポリマーの重量一幹ポリマーの重量 }}{\text { 反応したモノマーの重量 }}
$$$$
\times 100
$$

2.2.3 分子量の测定：得られたポリメタクリル酸メキル (PMMA) はクロロホルムを溶媒として Cannon Fenske 型粘度

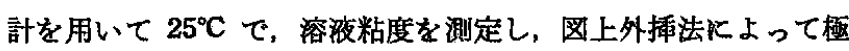
限粘度を求め，次式 ${ }^{25}$ 亿よって分子量を算出した。

$$
[\eta]=4.8 \cdot 10^{-5} \times M^{0.80}
$$

\section{3 実験結果ならびに考察}

\subsection{TBB の繦媒効果ならびにその藵度依存性}

重合開始剤として、TBB, BPO-ジメチルパラトルイジン, AIBN を用いてグラフト重合に批りる触媒活性を此較したが，TBB 以

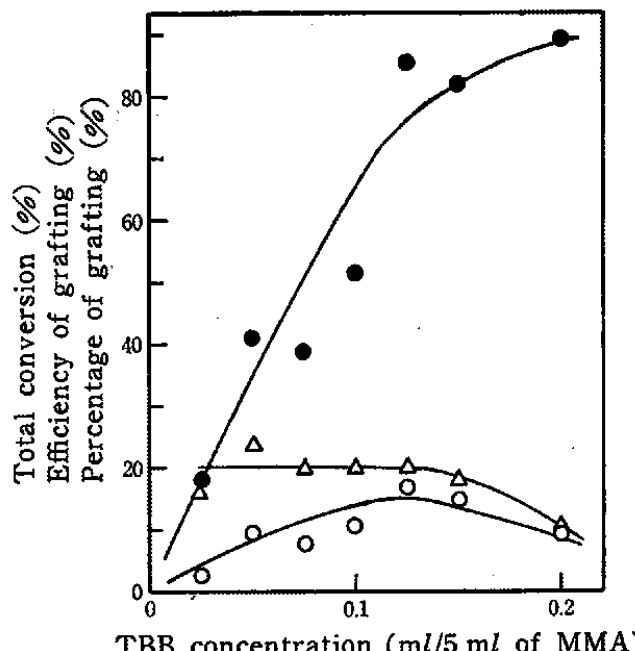

Fig. 1 Effects of TBB concentration on the grafting Silk $0.2 \mathrm{~g}$, MMA $5 \mathrm{ml}, \mathrm{H}_{2} \mathrm{O} 15 \mathrm{~m} l$ at $37^{\circ} \mathrm{C}$ for $1.5 \mathrm{hrs}$

0 : Total conversion, $\bigcirc:$ Percentage of grafting,

$\triangle$ : Efficiency of grafting

24） 48 時間の抽出で MMA のホモポりマーは底とんど完全に 抽出されるが，新しい抽出液が沈段剂を加えて白濁する場 合飞怯さら飞 24 時間抽出を行なった。

25) J. Bischoff, V. Desrewx, J. Polym. Sci., 10, 437(1953). 
外の開始剂では $37^{\circ} \mathrm{C}$ においてグラフト重合は起こらなかっった。 図1は TBB を用いて，その濃度の变化が全重合率，グラフト重 合率、グラフト效率飞和よ戊す影謷について調べた結果を図示し たるのである。

全重合率は TBB の濃度の増加ととすに增大する。この供向は 通常のラジカル重合反応と闰様であるが，グラフト重合率ならび にグラフト效率は 5 〜 $7.5 \times 10^{-4} \mathrm{~mol} / \mathrm{l}$ の付近で最高值を示し, さらに㳪度が高くなると減少する。

\section{2 亘合時间の影敏}

絹-水-MMA 系で TBB を開始剤とした場合の全重合率, グラ フト重合率，グラフト效率ならびに比較のために編を入れない系 の経時変化を図 2 に示した。

グラフト重合率は時間とともに增大する傾向が喼められるが， グラフト効率ははぼ一定の值を示す。重合時間を長くすると，グ ラフト重合率や重量増加率は增大するが，後で述べるように織維

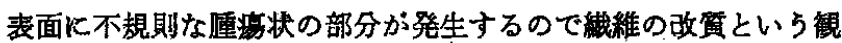
点からは好ましくない。短時間の処理で十分である。

\section{3 反応温度估存性}

図 3 は絹-本-MMA 系での重合温度の全重合率，グラフト重合 率, ならびにグラフト効率におよぼす影響を検討した結果を示し たものである。図から明らかなようにグラフト重合率，全重合率 は温度とともに増大するが，グラフト效率は这把淢少する傾向が 認められる。この事実は温度の上昇ととるにホモポリマーがでさ やすくなるが，グラフト活性点はほとんど增加しないことを意味 する。新井ら ${ }^{26)}$ は $\mathrm{LiBr}-\mathrm{K}_{2} \mathrm{~S}_{2} \mathrm{O}_{8}$ 系による絹への $\mathrm{MMA}$ のグラフ 卜重合に括いて、グラフト率は温度の高いほどよいと述べている が，著者らの系では低温の方がより效果的にグラフト重合を行な らことができる。

\section{$3.4 \mathrm{MMA}$ 濃度依存性ならびに水の影蛪}

モノマー灌度のグラフト重合への影響を調ベるため，モノマー

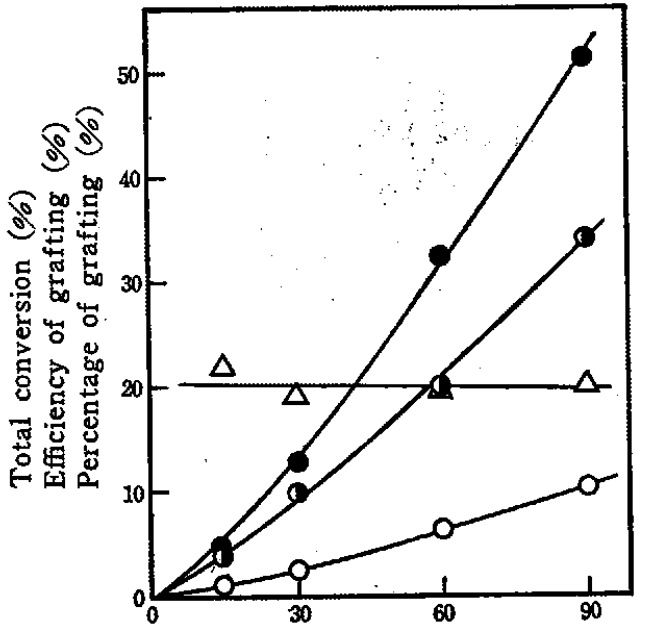

Polymerization time (min)

Fig. 2 Effects of polymerization time on the grafting Silk $0.25 \mathrm{~g}$, MMA $5.0 \mathrm{ml}$, TBB $0.1 \mathrm{ml}, \mathrm{H}_{2} \mathrm{O} 15 \mathrm{ml}$, at $37^{\circ} \mathrm{C}$, Swelling $24 \mathrm{hrs}$

: Total conversion, 0 : Total conversion without silk, $\bigcirc$ : Percentage of grafting, $\triangle$ : Efficiency of grafting

26）新井幸三，根岸道治，㵶学尌，23，595(1967)

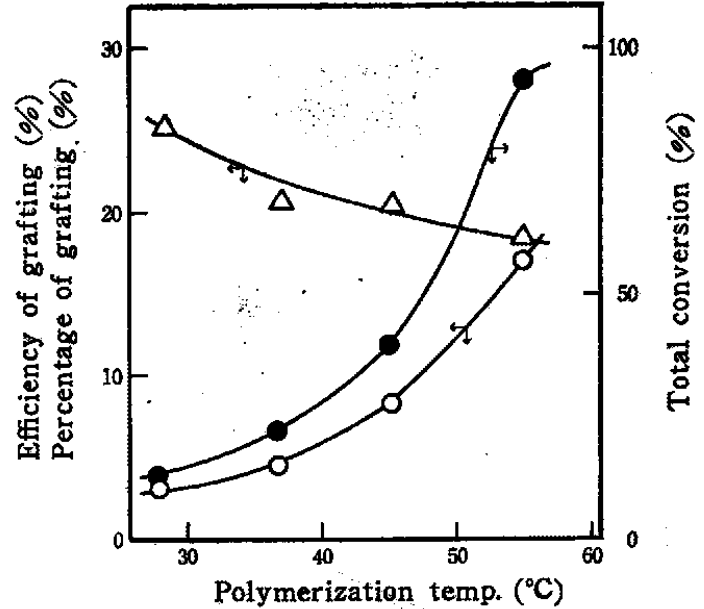

Fig. 3 Effects of polymerization temperature on the grafting

MMA $5 \mathrm{ml}$, TBB $0.1 \mathrm{ml}, \mathrm{H}_{2} \mathrm{O} 15 \mathrm{ml}$, Silk $0.3 \mathrm{~g}$, Swelling $24 \mathrm{hrs}$, Polymerization time $1 \mathrm{hr}$

: Total conversion, $O:$ Percentage of grafting, $\triangle:$ Efficiency of grafting

と水の比を変えてグラフト重合を行なった。すなわち絹 0.2 g, MMA と水の合計量を $20 \mathrm{ml}$ として，MMA の全系飞対する嘍 合を 10\% から $100 \%$ まで変化し，TBB と MMAの比（vol）

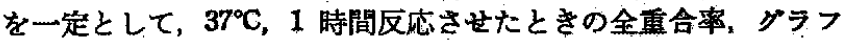
卜重合率,グラフト効率を検傠した。その結果を図 4 K示す。

図から明らかなよらに全重合率は MMA 漊度ととるに増大す るが, グラフト重合率, グラフト効率はいずれす MMA 漊度 50\% のところ最大値があらわれる。そして MMA 漊度 $100 \%$ ， つまり水が存在しない系では水モ重合のみが起こって、グラフト 共重合はほとんど起こらなかった。このことから MMA の絆へ のグラフト共重合には水が不可欠であることがわかる。なお罒中

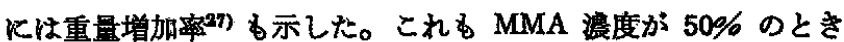

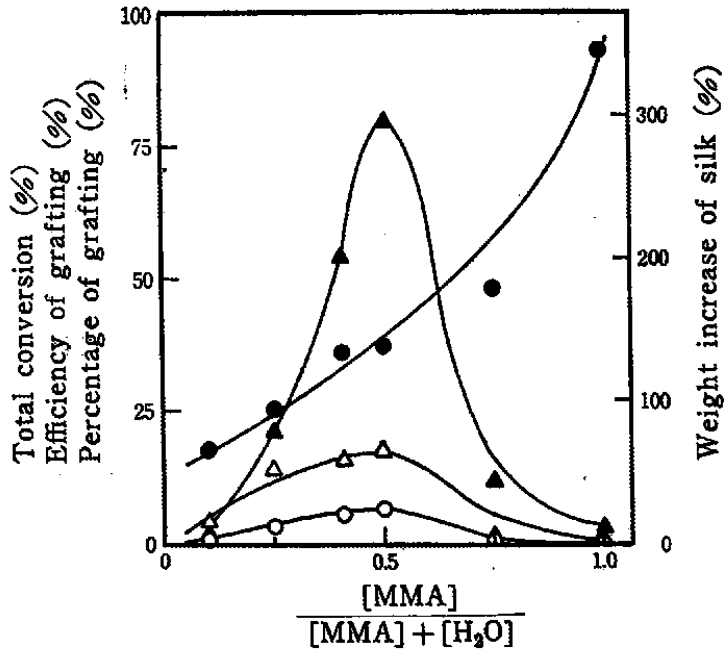

Fig. 4 Effects of MMA concentration on the grafting MMA $+\mathrm{H}_{2} \mathrm{O} 20 \mathrm{ml}$, TBB/MMA 0. 02, Silk $0.2 \mathrm{~g}$, Swelling $24 \mathrm{hrs}$, Polymerization time $1 \mathrm{hr}$, at $37^{\circ} \mathrm{C}$

: Total conversion, $O$ : Percentage of grafting,

$\triangle$ : Efficiency of grafting, $\Delta:$ Weight increase of silk

27）責疊増加率とはグラフトボリマーの幹ボリマーに対する割 合を重量百分必で表わしたるのである。 


\section{飞極大做が㐫らわれている。}

\section{5 絹量の影装}

MMA $5 \mathrm{ml}$, 水 $15 \mathrm{ml}, \mathrm{TBB} 0.1 \mathrm{ml}$ とし, 重合温度 $37^{\circ} \mathrm{C}$ て 絧量を 0.125〜0.447 g と変化したとさ，重合時間 2 時間で，全 重合率、グラフト重合率、グラフト效率がどの上5に变化するか を調べた。その結果を四 5 亿示す。

因から明らかなよらに全重合率が 15\% 以内のところでは，全 重合率，グラフト重合率，グラフト效率のいずれす綟の量飞比例

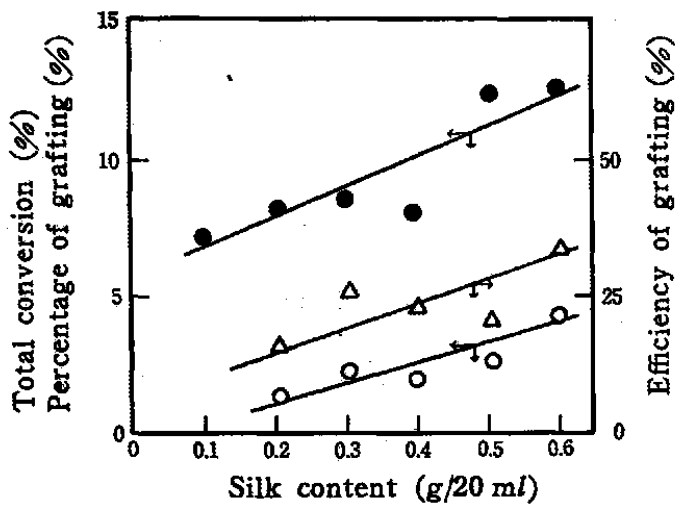

Fig. 5 Effects of silk content on the grafting MMA $5.0 \mathrm{ml}, \mathrm{H}_{2} \mathrm{O} 15 \mathrm{ml}$, TBB $0.1 \mathrm{ml}$, Swelling $24 \mathrm{hrs,}$ Polymerization time $30 \mathrm{~min}$, at $37^{\circ} \mathrm{C}$

: Total conversion, $O:$ Percentage of grafting, $\triangle:$ Efficiency of grafting

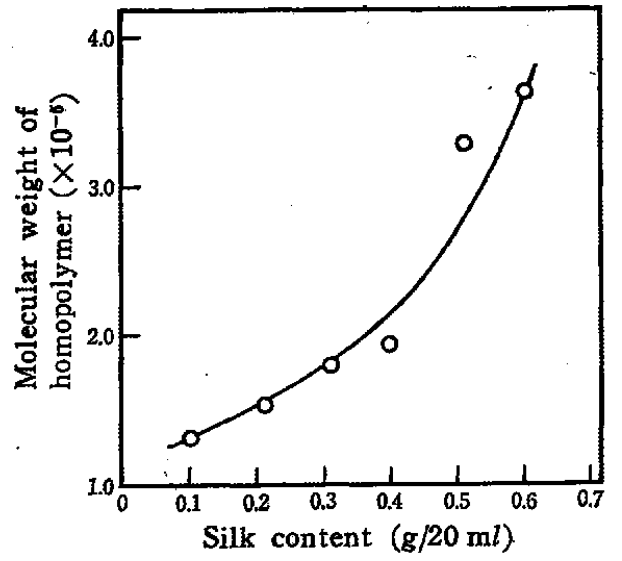

Fig. 6 Effects of silk content on the molecular weight of homopolymer

MMA $5.0 \mathrm{ml}, \mathrm{H}_{2} \mathrm{O} 15 \mathrm{~m} l$, TBB $0.1 \mathrm{~m} l$, Swelling $24 \mathrm{hrs,}$ Polymerization time $30 \mathrm{~min}$, at $37^{\circ} \mathrm{C}$
して增大している。この事実は編が開始反応関与していること を示するのである。そこでこの反応で得られたそれでれの示てポ リマーの平均分子量を粘度法によって測定してみた。その結果は

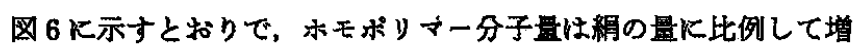
大している。

\section{6 首処理による影䈉}

3.5 K述べたよ5に編-TBB，あるいは絹-水-TBB のコンブレ ックスが MMA のグラフト重合に関与すると考えられるので， 絹をあらかしめ醕むるい性基, とくに塩基性アミノ酸で処理し て同様な実験を行ない，その全重合率，グラフト重合率，グラフ

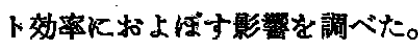

その結果を表 1 に示した。すなわち酸としては䣫酸、リン酸を， 塩基または塩基性アミノ酸としては,ピリジン、シシン、グアニ ンならびにアデニンを用い，それぞれ 0.1 1 mol\% 水溶液とし， その中編を 24 時間浸清し， 口紙ではさんで余分の本を除去し てから疌 $15 \mathrm{~m} l$ を入れた反応管飞入れ，TBB $0.1 \mathrm{~m} l$ を含む MMA $5 \mathrm{ml}$ を加えて $37^{\circ} \mathrm{C}$ で重合した。全重合率は水だけて脚 潤したすのに比較すると，酢酸、リン酸で処理したものは低下す るが、リシン、フデニンならびにグアニンで処理したるのは増大 している。またグラフト重合率も，これらの塩基性フミノ酸で処 理したるのは增大している。これらの事実からグラフト活性点と なるところは，塩基性フミノ酸残基ではなかららかと教えられる。

\section{7 グラフトボリマーの加水分解とアミノ酸分析}

3.6 K抢いてグラフト活性点は塩基性アミノ酸残基かす知れな いと考えられたので，むしグラフト重合によって塩基性アミノ酸 が消費されていれば，グラフト共重合体を加水分解し，溶解して くるアミノ酸を定量すれば塩基性アミノ酸は減少しているはずで ある。そこでさきの実験で得られたグラフト共重合体を $20 \%$ 水 酸化ナトリウム水溶液で加水分解してみた。

末処理の絹は約 10 時間, $80^{\circ} \mathrm{C}$ 飞加繁することによって注と んと加水分解するが，MMA ぞララフト重合したるのは非常に加 水分解し難くなる。たとえば重量增加率が $30 \%$ のものでも数週 間加水分解されず織維の形をととめているし，重量墥加率 100 $\%$ のものは 1 篁月間 $20 \%$ 水酸化ナトリウム水溶液中で $80^{\circ} \mathrm{C}$ K 加熱したがはとんど分解せず紻維の原形をととめていた。

重量增加率の低いグラフト体の加水分解生成物のアミノ酸分析 の結果を表 2 に示す。上飞述べたようにグラフト化が高度に起こ った試料は加水分解をらけ難いので，低いグラフト化度のるのに ついての分析結果の比較しかできないが，大きな变化は認められ なかった。ただしセリンがいちしるしく滅少していることは明ら

Table 1 Effects of pretreatment

\begin{tabular}{llcccccc}
$\begin{array}{c}\text { Exp. } \\
\text { No. }\end{array}$ & Pretreatment & $\begin{array}{c}\text { Weight of } \\
\text { silk } \\
(\mathrm{g})\end{array}$ & $\begin{array}{c}\text { Total } \\
\text { yield } \\
(\mathrm{g})\end{array}$ & $\begin{array}{c}\text { Total } \\
\text { conversion } \\
(\%)\end{array}$ & $\begin{array}{c}\text { Weight of } \\
\text { graft poly- } \\
\text { mer }(\mathrm{g})\end{array}$ & $\begin{array}{c}\text { Efficiency } \\
\text { of grafting } \\
(\%)\end{array}$ & $\begin{array}{c}\text { Percentage } \\
\text { of grafting } \\
(\%)\end{array}$ \\
\hline $11-1$ & Water & 0.207 & 2.631 & 51.4 & 0.806 & 24.7 & 12.7 \\
$11-2$ & Acetic acid & 0.204 & 1.418 & 25.8 & 0.486 & 23.2 & 6.0 \\
$11-3$ & Phosphoric acid & 0.214 & 1.843 & 34.6 & 0.381 & 10.3 & 3.5 \\
$11-4$ & Pyridine & 0.209 & 2.436 & 47.2 & 0.791 & 26.2 & 12.4 \\
$11-5$ & Lysine & 0.215 & 3.221 & 63.8 & 0.986 & 25.6 & 16.4 \\
$11-6$ & Adenine & 0.210 & 2.821 & 55.4 & 0.943 & 28.1 & 15.4 \\
$11-7$ & Guanine & 0.217 & 3.976 & 79.8 & 0.960 & 19.8 & 15.8
\end{tabular}

Results obtained under the following conditions: MMA $5.0 \mathrm{ml}, \mathrm{TBB} 0.1 \mathrm{ml}, \mathrm{H}_{2} \mathrm{O} 15 \mathrm{~m} l$, for $100 \mathrm{~min}$, at $37^{\circ} \mathrm{C}$ and Pre-treatment $24 \mathrm{hrs}$. 
Table 2 Amino acid analysists of exaft copolymer Amino acid content (molos)

Amino acld

\begin{tabular}{ccc}
\hline Silk & Silk & Silk \\
untreated & $1 \%$ graft & 39. $5 \%$ graft
\end{tabular}

\begin{tabular}{lrrr}
\hline Lysine & 1.5 & 1.3 & 1.4 \\
Aopartic acid & 3.8 & 3.8 & 3.4 \\
Threonine & 1.0 & - & - \\
Serine & 13.2 & 6.5 & 5.1 \\
Glubamic acid & 1.7 & 1.9 & 2.5 \\
Glycint & 41.1 & 40.0 & 43.7 \\
Alanine & 29.1 & 31.4 & 34.1 \\
Valine & 1.9 & 9.3 & 3.2 \\
Iso-leasine & 0.3 & 0.3 & 0.3 \\
Leunine & 0.6 & 0.9 & 0.7 \\
Tyrosine & 5.0 & 5.1 & 4.8 \\
Phenjl alanine & 0.6 & trace & 0.7
\end{tabular}

c) Analysed by Shibata 1 A-500 amino actd analyser.

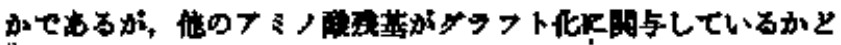
らかは明らかトナることはでをかかった。

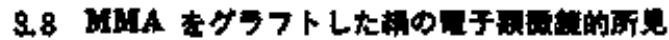

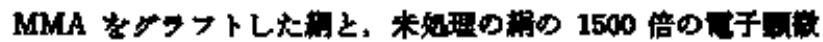

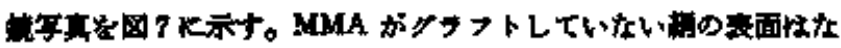

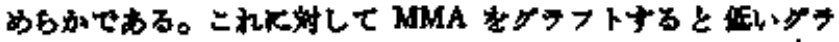

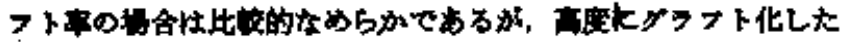

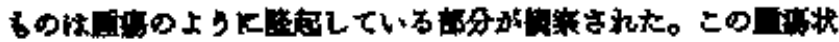

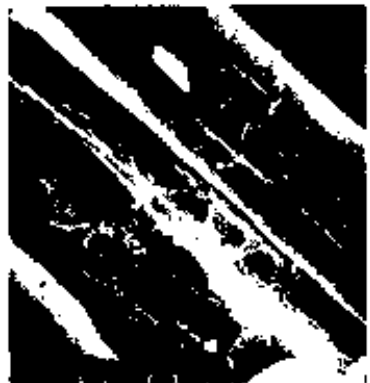

Untreated sillk

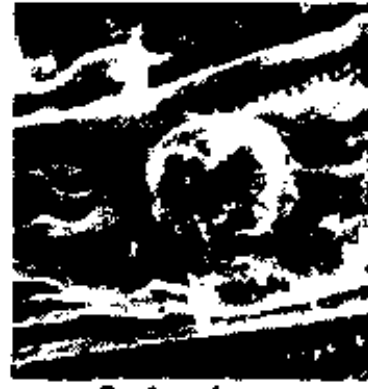

Graft polymer
Fig. 7 Electron micrograph of the graft copolymers X1500 (viewed in a JELCO JSM-13 electron microscope)

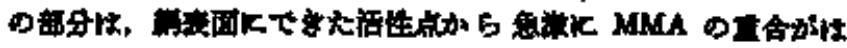

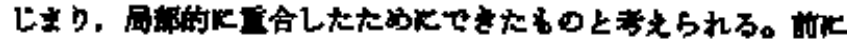

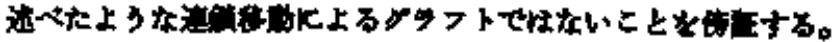

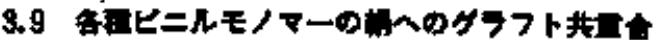

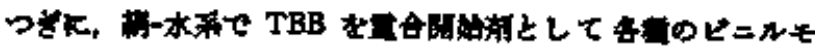

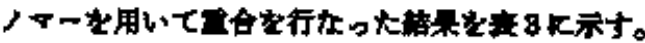

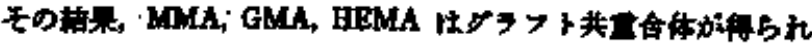

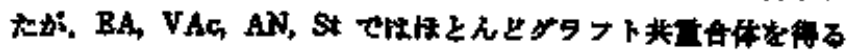

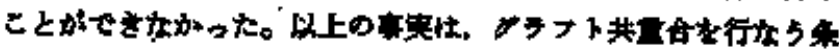

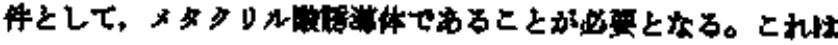

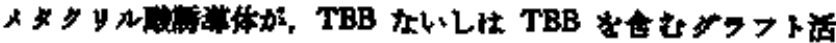

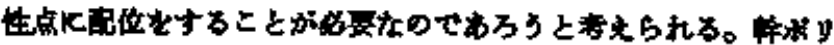

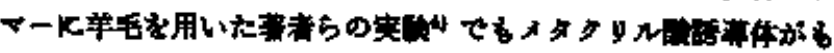

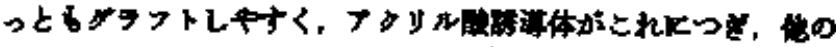

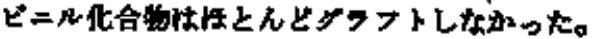

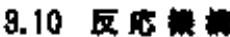

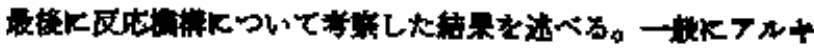

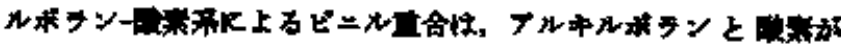

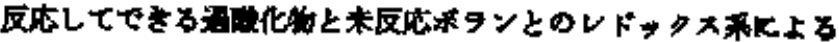

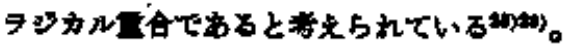

$$
\begin{aligned}
& \mathrm{R}_{-} \mathrm{B}+\mathrm{O}_{\mathbf{2}} \longrightarrow \mathrm{ROOBR}_{\mathbf{2}} \\
& \text { ROOBR }_{3}+2 \mathrm{R}_{\mathbf{l}} \mathrm{B} \longrightarrow \mathrm{R}_{\mathbf{3}} \mathrm{BOBR}_{\mathbf{A}}+\mathrm{R}_{\mathrm{H}} \mathrm{BOR}+2 \mathrm{R} \text {. }
\end{aligned}
$$

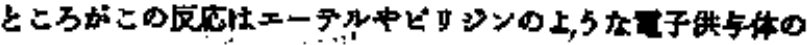

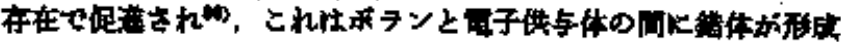

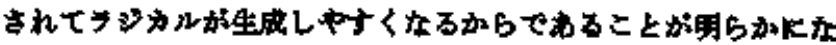
$\rightarrow$ た14.

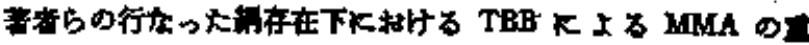

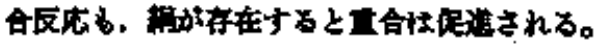

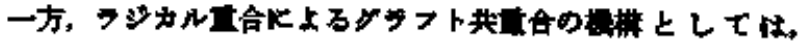

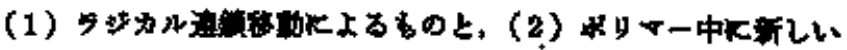

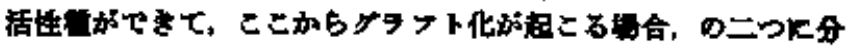

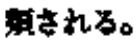

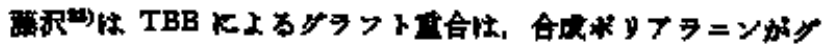

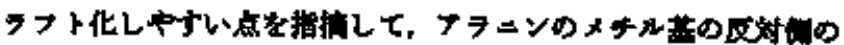

\begin{tabular}{|c|c|c|c|c|c|c|c|}
\hline $\begin{array}{l}\text { Exp. } \\
\text { Na. }\end{array}$ & Monomer & $\begin{array}{l}\text { Weight of } \\
\text { sill } \\
\text { (a) }\end{array}$ & $\begin{array}{l}\text { Totnd } \\
\text { rield } \\
\text { (E) }\end{array}$ & $\begin{array}{c}\text { Total } \\
\text { conversion. } \\
\text { (g\%) }\end{array}$ & $\begin{array}{l}\text { Weight of } \\
\text { Eraft poly: } \\
\text { mer }(\boldsymbol{X})\end{array}$ & $\begin{array}{l}\text { Efficiency } \\
\text { of prafting } \\
(\%)\end{array}$ & $\begin{array}{c}\text { Percentage } \\
\text { of istifino } \\
(\approx)\end{array}$ \\
\hline $12-1$ & MMA & 0.210 & 2.015 & 8.3 & 0.392 & 21.7 & 8.3 \\
\hline $12-2$ & EA & 0.198 & 4. 476 & 97.3 & 0.000 & - & - \\
\hline $12-3$ & GMA & 0. 2003 & 5. 054 & 91.2 & 1.648 & 84. 1 & 30.8 \\
\hline $12-4$ & VAC & 0.208 & 3.586 & 72.3 & 0.085 & 0.7 & 0.5 \\
\hline 12-5 & VP & a. 200 & 0.257 & 1.0 & 0.000 & - & - \\
\hline 12-6 & HEMA & 0.207 & 3. 494 & 59.9 & 2828 & 71.9 & 4. 1 \\
\hline
\end{tabular}

Table 3 Graft-copolymerization of varieous vinyl monomer onto sllk

Results obtained under the following conditions:

Monomer : $5.0 \mathrm{ml}$, TBB : $0.1 \mathrm{ml}, \mathrm{B}, 0: 15 \mathrm{ml}$, for $90 \mathrm{~min}$ at $37 \mathrm{C}$ and Swelling $24 \mathrm{hrs}$.

MMA : Methyl methacrylate, EA : Bthyl acrylate, VP : N-VInyl-2-pyralidone, GMA : Glycidyl methacrylate, VAc: Vinyl acetete, HEMA : 2-Hydroxyethyl methacrylate.

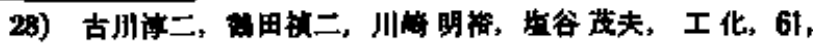
1362 (1968).

29) G. Talamini, G. Vidolette, Mahromal. Chem, 53, 2191 (1962).

30) G. Broghini M. Cipola, J. Polym. Sci., B 2, 2910(1964).
81) K. Kojlma, Y. Iwata, M. Nagayama, S. Jwabuchi, J. Polym, Sci, B8, 541(1970).

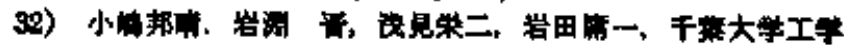

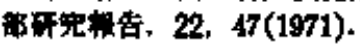

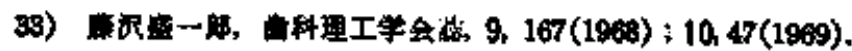


承素が引き掖かれて，ポリファニンラジカルを生成し，ここから グシフト化が起こると報告している。つまり連鑟移動比よるるの と考えている。るしこのような機構を考えるならば, グラフトポ リマ一の枝の部分の分子量は，木モポリマ一のそれと同一である こをが，來ら らな，种量が増すとホモポリマーの分子量が増大することは竞明 できない。桷の量が堌すと当然連鎖移動は起こりやすくなり，乙 たがってホモポリマーの分子量性減少すると考えられるからであ る。

著者らはすでに TBB によるセルロース存在下における MMA の重合反応化ついて换討し，セルロースは TBB と錯体を形成し， これから新しいラジカルを生成して MMA を重合させると考え $t^{35)}$ 。

节本ら ${ }^{36)}$ は種々の高分子化合物は水が存在すると MMA の重 合を促進することを琶め，これ対して本と MMA と高分子化 合物の間飞錯体を形成し、これからラジカルを生成してグラフト

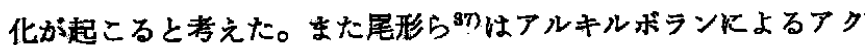
リロニトリル（AN) の重合反応に扎いて，開始反応にモノマーが 関与しており，AN-ボラン配位化合物が重合を開始すると報告し ている。一方，アルキルボランはアミンのような電子供与体と分 子化合物をつくことが知られている

以上のような專実を考虑して，TBB は絹の構成成分ならびK MMA の関与した活牲錯合体をつくりこれがグタフト重合を開

34) Y.Mori, Y.Minoura, M. Imoto, Makromol. Chem., 25 , 1(1957).

35) K. Kojima, S. Iwabuchi, K. Murakami, F. Ichikawa, J. Appl. Polym. Sci., 16, 1139(1972).

36) M. Imoto, K. Takemoto, T. Otsuki, Makromol. Chem., 104, 244(1967).

37）尾形弥生, 箕浦有二, 工化, 66, 1707(1963).

38) H. C. Brown, G. K. Barbaris, J. Amer. Chem. Soc., 69, $1137(1942)$.
始すると考えると実姶事実を矛盾なく䂱明できる。

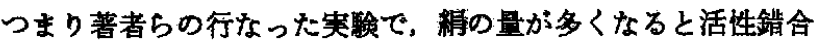
体の形成使われる TBB の量が多くなり，遊離の TBB の量が 減少する。遊離の TBB は主としてホモホリマーの生成に関与す ると考えれば，任込の MMA と TBB の比が一定ならば，当然 その分子量恃增大することになる。 な TBB 単独よりす TBB網錯合体の方が活性が高いから全取率は綟の量が増すと增大す る。

グヨフトポリマーは絹中の活性点となるべきアミノ酸残基と TBB の量が，見合ったところに最大值があらわれるはずで，こ れらは実験事実とよく一致する。

つぎにグラフトポりマーの加水分解物のア、ノ酸分析の結果は， 未処理の絹の加水分解物のそれと比較すると，セリンがとくに顕 著飞㳚少している。この事実はせりンのような親水基をるつアミ ノ酸が活性錯合体の生成に関与するのではないかと考党られるが， いまだ明確ではない。また 3.4 で述べたように，このグラフト化 飞は水の存在が必要で, 水で膨潤しない絹を用いるとグラフト化

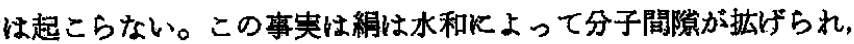
活性鍇合体の形成が容易となり，同時に MMA の浸入が容易に なるすのと考えられる。以上要するに TBB による MMA の綟 へのグラフト重合は, (1) 絧の水和,（2）水和した絹-TBBMMA の錯合体の形成，（3）錯合体からのグラフト活性点の形 成，のよらな機構を経て進行するるのと考えられる。

水和した緝 $+\mathrm{TBB}+\mathrm{MMA} \longrightarrow$ 一錯合体 $] \longrightarrow$ 一゙ラフト活性点

本研究にあたり，御指導衔討論をいただいた東京医科画科大学 医用器材研究所增原英一教授，同大学院学生藤沢盛一郎氏，小島 幸一氏に，また電子影德鏡写真の撮映をしていたたいた渡辺昭彦

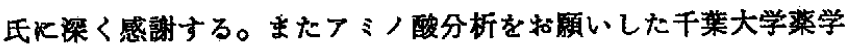
部村越 勇助教授飞感謝する。

（1971 年 4 月，日本化学会第 24 年会（一部）講演）

Tri-butylborane Initiated Graft-copolymerization of Methyl Methacrylate onto Silk

Kuniharu Kojima*, Takao Suzuki*, Susumu Iwabuchi* and Niro TARUMI**

* Department of Applied Chemistry, Faculty of Engineering, Chiba University ; Yayoi-cho, Chiba-shi, Japan

** Institute for Medical and Dental Engineering, Tokyo Medical and

Dental University; Kanda-surugadai, Chiyoda-ku, Tokyo, Japan

The Graft-copolymerization of methyl methacrylate (MMA) onto silk by tri-butylborane (TBB) was investigated in aqueous medium. It was found that the polymerization of MMA was accelerated in the presence of silk and the graft copolymer was obtained, while no grafting occurred in the absence of water. With rising temperature the rate of polymerization increased and the efficiency of grafting decreased. Both the percentage of grafting and the molecular weight of the polymer increased with increasing amount of silk. And also the percentage of grafting and the efficiency of grafting were increased by the pretreatment of basic amino acids.

Glycidyl methacrylate and 2-hydroxyethyl methacrylate were also grafted onto silk, while no grafting was observed with other vinyl monomers. Amino acid analysis of hydrolysis products and their electron microscopic observation were made on the graft copolymers. On the basis of these results, the mechanism of grafting is discussed. 